\title{
FAKTOR-FAKTOR RISIKO TERHADAP OBESITAS PADA REMAJA DI KOTA BITUNG
}

\author{
${ }^{1}$ Christine Hendra \\ ${ }^{2}$ Aaltje E. Manampiring \\ ${ }^{2}$ Fona Budiarso
}

\author{
${ }^{1}$ Kandidat Skripsi Fakultas Kedokteran Universitas Sam Ratulangi Manado \\ ${ }^{2}$ Bagian Kimia Fakultas Kedokteran Universitas Sam Ratulangi Manado \\ Email: christaliahendra@ymail.com
}

\begin{abstract}
Obesity is defined as a condition of abnormal or excessive fat accumulation in adipose tissue which can be harmful for health. The risk factors that can affect obesity in adolescent are dietary habit, lifestyle, physical activity, environmental factor, genetics, health factor, psychological and hormonal drugs. The purpose of this study was to determine the prevalence and risk factors for obesity in adolescent. This study used cross sectional method with descriptive approach, the sampling technique used in this study is simple random sampling. Samples are 966 students which met the inclusion criteria were 15 to 18 years old, was willing to be sampled. Data retrieval is done by measuring waist circumference. Conclusion: Based on the waist circumference measurement of 966 populations, 220 peoples are found obese with presentation of $22,8 \%$ consisting of 59 boys with presentation $6,1 \%$ and 161 girls with presentation of $16,7 \%$. Based on the research result, dietry habit is the most affecting factor in obesity, followed by genetic factor, lifestyle, physical activity and environmental factor and the last are health factor and psychological.
\end{abstract}

Keywords: obesity, adolescents, risk factor.

\begin{abstract}
Abstrak: Obesitas didefinisikan sebagai suatu kondisi akumulasi lemak yang tidak normal atau berlebihan di jaringan adiposa sampai kadar tertentu sehingga dapat merusak kesehatan. Faktor-faktor risiko yang dapat menpengaruhi terjadinya obesitas pada remaja adalah pola makan, pola hidup, aktivitas fisik, faktor lingkungan, genetik, faktor kesehatan, psikis dan obat-obatan hormonal. Tujuan penelitian ini adalah untuk mengetahui prevalensi dan faktorfaktor risiko terhadap obesitas pada remaja. Penelitian ini menggunakan metode cross sectionaldengan pendekatan dekskriptif. Teknik pengambilan sampel yang digunakan adalah dengan menggunakan cara simple random sampling. Sampel penelitian sebanyak 966 siswa yang memenuhi kriteria inklusi yang berusia 15-18 tahun, bersedia menjadi sampel. Pengambilan data dilakukan dengan cara pengukuran lingkar pinggang. Simpulan: Berdasarkan hasil pengukuran lingkar pinggang pada 966 populasi didapatkan 220 orang mengalami obesitas dengan presentasi $22,8 \%$ yang terdiri dari 59 orang laki-laki dengan presentase $6,1 \%$ dan 161 orag perempuan dengan presentase $16,7 \%$. Berdasarkan hasil penelitian juga didapatkan bahwa pola makan merupakan faktor risiko paling berpengaruh pada obesitas kemudian diikuti dengan faktor genetik, pola hidup, aktivitas fisik dan faktor lingkungan dan yang terakhir adalah faktor kesehatan dan psikis.
\end{abstract}

Kata kunci: obesitas, remaja, faktor risiko.

Obesitas adalah suatu penyakit serius yang dapat mengakibatkan masalah emosional dan sosial. Seorang dikatakan overweight bila berat badannya 10\% sampai dengan $20 \%$ berat badan normal, sedangkan seseorang disebut obesitas apabila 
kelebihan berat badan mencapai lebih 20\% dari berat normal. Obesitas saat ini menjadi permasalahan dunia bahkan Organisasi Kesehatan Dunia (WHO) mendeklarasikan sebagai epidemic global. ${ }^{1}$

Masalah obesitas banyak dialami oleh beberapa golongan masyarakat salah satunya remaja. Kelebihan berat badan pada remaja telahdi hubungkan dengan naiknya kadar insulin plasma, lipid darah, dan kadar lipoprotein naik, dan kenaikan tekanan darah, yang merupakan faktor yang diketahui dihubungkan dengan morbiditas orang dewasa akibat obesitas. ${ }^{1}$

Obesitas ini disebabkan karena aktivitas fisik yang kurang, disamping masukan makanan padat energi yang berlebihan. Obesitas pada remaja meningkatkan risiko penyakit kardiovaskuler pada saat dewasa karena kaitannya dengan sindroma metabolik yang terdiri dari resistensi insulin/hiperinsulinemi, intoleransi glukosa/diabetes melitus, dislipidemia, hiperurisemia, gangguan fibrinolisis, dan hipertensi. ${ }^{1,2}$

Prevalensi obesitas menurut Riset Kesehatan Dasar (Riskesdas) 2013 meningkat jika dibandingkan dengan Riskesdas 2010. Angka obesitas pria pada 2010 sekitar 15 persen dan sekarang menjadi 20 persen. Pada wanita persentasenya dari 26 persen menjadi 35 persen. $^{3}$

Setiap orang memerlukan sejumlah lemak tubuh untuk menyimpan energi, sebagai penyekat panas, dan fungsi lainnya. Rata-rata wanita memiliki lemak tubuh yang lebih banyak dibandingkan pria. Perbandingan yang normal antara lemak tubuh dengan berat badan adalah sekitar $25-30 \%$ pada wanita dan $18-23 \%$ pada pria. Wanita dengan lemak tubuh lebih dari 30\% dan pria dengan lemak tubuh lebih dari 25\% dianggap mengalami obesitas. Seseorang yang memiliki berat badan 20\% lebih tinggi dari nilai tengah kisaran berat badannya yang normal dianggap mengalami obesitas. ${ }^{4,5}$

Untuk menentukan seseorang menderita obesitas atau tidak, cara yang paling banyak digunakan adalah menggunakan Index Massa Tubuh (IMT). IMT ditujukan dengan perhitungan kilogram per meter kuadrat $\left(\mathrm{kg} / \mathrm{m}^{2}\right)$, berkorelasi dengan lemak yang terdapat dalam tubuh. ${ }^{6}$

Berikut tipe obesitas berdasarkan bentuk tubuh. Obesitas tipe buah apel (Apple Shape) Tipe seperti ini biasanya terdapat pada pria. Dimana lemak tertumpuk di sekitar perut. Risiko kesehatan pada tipe ini lebih tinggi dibandingkan dengan buah pear (Gynoid). Obesitas tipe buah pear (Gynoid) Tipe ini cenderung dimiliki wanita, lemak yang ada disimpan di sekitar pinggul dan bokong. Risiko terhadap penyakit pada tipe gynoid umumnya kecil. Obesitas tipe Ovid (Bentuk Kotak Buah) Ciri dari tipe ini adalah "besar di seluruh bagian badan". Tipe Ovid umumnya terdapat pada orangorang yang gemuk secara genetik. ${ }^{4,7}$

Faktor-faktor risiko terhadap obesitas sepeti pola makan, gaya hidup, kurangnya aktivitas dan kurangnya kesadaran pada remaja jika tidak diupayakan perbaikannya akan mempengaruhi kualitas masyarakat di masa mendatang. ${ }^{8}$ Faktor-faktor seperti lingkungan, genetik, psikis, kesehatan, dan juga obat-obatan. ${ }^{9}$ Gambaran status gizi dan pengetahuan di masa sekarang berdampak besar pada gambaran status gizi di masa mendatang, Sehingga perlu dicari informasi mengenai faktor-faktor risiko terhadap obesitas, khususnya faktor-faktor risiko yang banyak muncul pada remaja siswa/siswi SMA yang obesitas.

Penelitian Setyaninggrum (2007) memperlihatkan bahwa 34,4\% responden remaja usia pubertas sering mengonsumsi makanan siap saji. Hasil penelitian memperlihatkan bahwa ada hubungan yang bermakna antara konsumsi makanan cepat saji dengan kejadian obesitas. ${ }^{10,11}$

Tujuan penelitian ini adalah untuk mengetahui prevalensi obesitas pada remaja di Kota Bitung, dan mengetahui faktor-faktor risiko terhadap obesitas pada remaja di Kota Bitung. 


\section{METODE PENELITIAN}

Penelitian ini adalah penelitian Cross Sectional dengan pendekatan dekskriptif. Penelitian dilakukan di SMA/SMK di Kota Bitung dari bulan Oktober 2015 sampai Januari 2016. Populasi dalam penelitian ini adalah remaja yang berusia 15 sampai 18 tahun di SMA/SMK di Kota Bitung. Sampel yang diambil adalah remaja dengan lingkar pinggang untuk Laki-laki $>90$ dan Perempuan $>80$. Sampel diambil dengan cara simple random sampling.

\section{HASIL PENELITIAN}

Penelitian dilakukan dengan melakukan pengukuran lingkar pinggang secara acak terhadap 966 orang remaja yang mewakili Sekolah - sekolah Menengah Atas di Kota Bitung yang terdiri dari usia 15-18 tahun. Didapatkan 966 orang remaja yang menjadi populasi target, berdasarkan dengan pengukuran lingkar pinggang didapati ada 220 orang remaja dengan obesitas, dan yang menyetujui untuk diwawancarai adalah 50 orang remaja obesitas.

Tabel 1. Prevalensi obesitas pada remaja di Kota Bitung

\begin{tabular}{|c|c|c|c|c|}
\hline \multirow[t]{2}{*}{ No } & \multirow{2}{*}{$\begin{array}{c}\text { Jenis } \\
\text { Kelamin }\end{array}$} & \multirow[t]{2}{*}{$n$} & \multicolumn{2}{|c|}{ Lingkar pinggang } \\
\hline & & & $\begin{array}{c}\text { Normal } \\
(\%)\end{array}$ & $\begin{array}{c}\text { Obesitas } \\
\text { (\%) }\end{array}$ \\
\hline 1 & L & 382 & $33,4 \%$ & $6,10 \%$ \\
\hline 2 & $\mathrm{P}$ & 584 & $43,8 \%$ & $16,7 \%$ \\
\hline & & 966 & $77,2 \%$ & $22,8 \%$ \\
\hline
\end{tabular}

Batasan ukuran Lingkar Pinggang berdasarkan IDF:

Laki - laki $\quad:>90 \mathrm{~cm}$

Perempuan : $>80 \mathrm{~cm}$

Berdasarkan batasan Lingkar Pinggang ditemukan 22,8\% remaja obesitas di Kota Bitung, dan yang bersedia untuk diwawancarai ada 50 orang remaja obesitas.

Berdasarkan Tabel 2 secara keseluruhan didapatkan faktor risiko terjadinya obesitas yang tertinggi disebabkan oleh faktor pola makan (PM) dengan hasil sebanyak 49 (98\%) orang, lalu diikuti faktor riwayat keturunan (RK) sebanyak 38 (76\%) orang, kemudian faktor aktivitas fisik (AF) sebanyak 12 (24\%) orang dan yang paling sedikit pada faktor psikis (P) dengan hasil sebanyak 7 (14\%) orang. Didapatkan hasil demikian karena pada satu individu bisa terdapat lebih dari satu faktor resiko.

Tabel 2. Karakteristik responden berdasarkan faktor-faktor risiko secara keseluruhan

\begin{tabular}{cccccc}
\hline & $\begin{array}{c}\mathrm{N} \\
(\%)\end{array}$ & PM & AF & P & RK \\
\hline & & $\mathrm{N}$ & $\mathrm{N}$ & $\mathrm{N}$ & $\mathrm{N}$ \\
Total & 50 & $(\%)$ & $(\%)$ & $(\%)$ & $(\%)$ \\
& & $99 \%$ & 12 & 7 & 38 \\
& & $98 \%$ & $14 \%$ & $76 \%$ \\
\hline
\end{tabular}

\section{BAHASAN}

Penelitian yang dilakukan di Sekolah sekolah Menengah Atas di Kota Bitung pada bulan Oktober 2015 - Januari 2016 terhadap 966 orang remaja yang berusia 15-18 tahun berdasarkan ukuran lingkar pinggang ditemukan 220 orang remaja yang mengalami obesitas yang terdiri dari 59 orang laki-laki dan 161 orang perempuan.

Berdasarkan hasil pengukuran lingkar pinggang pada 966 populasi didapatkan 220 orang remaja yang mengalami obesitas dengan presentase sebesar 22,8\% yang terdiri dari 59 orang laki-laki dengan presentase $6,1 \%$ dan 161 orang perempuan dengan presentase $16,7 \%$, dan yang bersedia untuk diwawancarai ada 50 orang remaja obesitas.

Berdasarkan hasil penelitian yang dilakukan pada 50 orang terdapat 49 orang remaja dengan presentase $98 \%$ yang mengalami obesitas berdasarkan pola makan. Hal ini menjelaskan bahwa pola makan merupakan faktor risiko yang paling berpengaruh terhadap obesitas pada remaja. Kehidupan remaja di Kota Bitung mempunyai kebiasaan mengkonsumsi makanan tinggi karbohidrat, lemak, gula serta kebiasaan mengkonsumsi makanan siap saji. Masalah gizi atau pola makan yang sering terjadi pada remaja adalah 
ketidakseimbangan antar konsumsi gizi dengan kecukupan gizi yang dianjurkan. Remaja di Kota Bitung sering mengkonsumsi makanan yang mengandung tinggi karbohidrat seperti nasi dan umbiumbian serta lemak yang berasal dari gorengan yang pada dasarnya merupakan makanan yang digemari remaja pada umumnya, konsumsi makanan siap saji juga merupakan faktor yang berpengaruh pada penumpukan lemak tubuh karena jumlah kalori yang terdapat pada makanan siap saji dalam sekali makan melebihi angka kecukupan kalori harian. ${ }^{1,2,9}$

Hasil penelitian juga didapatkan bahwa faktor riwayat keturunan juga mempunyai peran yang cukup besar terhadap terjadinya obesitas pada remaja yaitu 38 orang remaja dengan presentase $76 \%$ dari hasil penelitian pada 50 orang remaja obesitas di Kota Bitung, hal ini menjelaskan bahwa faktor genetik juga mempunyai peran dalam terjadinya obesitas, remaja dengan obesitas cenderung memiliki orang tua yang obesitas. $^{4,7}$

Faktor pola hidup, aktivitas fisik dan lingkungan juga berperan terhadap terjadinya obesitas, dari hasil penelitian terhadap 50 orang remaja obesitas didapatkan bahwa 12 orang remaja dengan presentase $24 \%$ yang mengalami obesitas berdasarkan faktor pola hidup, aktivitas fisik dan lingkungan. Remaja yang kurang melakukan aktivitas fisik cemderung mengalami obesitas karena kurangnya aktivitas menyebabkan menumpuknya lemak tubuh dengan berlebihan, kurangnya aktivitas fisik yang tidak mengimbangi asupan makan juga menjadi pemicu terjadinya obesitas pada remaja. Kemajuan teknologi masa kini membuat para remaja lebih sering menghabiskan waktu dengan duduk berjam-jam memainkan smartphone, main komputer dan juga menonton TV sehingga kurangnya melakukan aktivitas lainnya seperti bermain sepak bola atau olahraga lainnya ${ }^{1,2,10}$

Hasil dari penelitian juga menunjukan bahwa faktor psikis mempengaruhi terjadinya obesitas pada remaja yaitu 7 orang remaja dengan presentase $14 \%$ dari hasil penelitian pada 50 orang remaja obesitas, stress atau kekecewaan yang biasanya dialami oleh remaja biasanya mempengaruhi peningkatan nafsu makan, gangguan pola makan akibat stress dapat berupa pola makan berlebihan atau nafsu makan yang meningkat ketika menggalami stress karena masalah yang sering terjadi pada masa remaja. ${ }^{4,7}$

\section{SIMPULAN}

Prevalensi obesitas pada remaja di Kota Bitung berdasarkan Lingkar Pinggang adalah sebesar 22,8\% yang terdiri dari 59 orang laki-laki dengan presentase $6,1 \%$ dan 161 orang perempuan dengan presentase $16,7 \%$.

Faktor-faktor risiko yang berpengaruh terhadap obesitas pada remaja di Kota Bitung yang tertinggi adalah faktor pola makan yaitu sebesar 98\%. Faktor risiko yang berpengaruh kedua adalah faktor riwayat keturunan yaitu sebesar $76 \%$. Faktor risiko yang berpengaruh ketiga adalah faktor pola hidup, aktivitas fisik dan lingkungan yaitu sebesar 24\%. Faktor risiko lainnya adalah faktor psikis dalam hal ini stress atau kekecewaan yaitu sebesar $14 \%$.

\section{SARAN}

Perlu dilakukan penelitian yang lebih lanjut mengenai faktor-faktor risiko dan hubungan langsung dengan obesitas dengan menggunakan sampel yang lebih banyak sehingga memperoleh hasil yang lebih jelas.

\section{DAFTAR PUSTAKA}

1. Susi Muktiharti, Purwanto, Imam Purnomo, Rosmiati Saleh. Fakultas Ilmu Kesehatan, Program Studi Kesehatan Masyarakat, Universitas Pekalongan. Faktor Risiko Kejadian Obesitas pada Remaja SMA Negeri 2 dan SMA Negeri 3 di Kota Pekalongan Tahun 2010. Diunduh dari:http://www.download.portalgaru da.org/ipi21062.pdf. Akses: 17 September 2015.

2. Tolombot, Krisma Juliana Mazniati. 2013. Skripsi Prevelensi Obesitas 
Pada Remaja di SMP Negeri 8 Manado.

3. Jumlah Orang Gemuk Bertambah. Diunduh dari:

http:/health.kompas.com/read/2014/0 8/20/170610223/Jumlah.Orang.Gemu k.Terus.Bertambah. Akses: 17 September 2015.

4. Obesitas. Diunduh dari: http://id.wikipedia.org/wiki/obesitas. Akses: 23 September 2015.

5. Overweight \& Obesitas sebagai suatu Risiko Penyakit Degeneratif. Diunduh dari: http://faikao.com/2011. Akses: 23 September 2015.

6. Sugondo S. Obesitas. Dalam Buku Ajar Ilmu Penyakit Dalam. Jilid III Edisi ke-5.Jakarta: Departemen Ilmu Penyakit Dalam Fakultas Kedokteran Universitas Indonesia; 2009. P.19731983.
7. Obesitas. Diunduh dari: http://id.scribd.com. Akses: 23 September 2015.

8. Anonimous. Obesitas. Diunduh dari: http://repository.usu.ac.id/bitstream/... /5/Chapter\%20I.pdf. Akses: 18 September 2015.

9. Supriyanto, Agus. 2013. Obesitas, Faktor Penyebab dan Bentuk-bentuk Terapinya. Diunduh dari: http://id.scrib.com. Akses: 5 Oktober 2015.

10.Adityawarman. 2007. Hubungan Aktivitas Fisik dengan Komposisi Tubuh pada Remaja. Diunduh dari: http://eprints.undip.ac.id/22215/1/Adi tya.pdf. Akses: 25 September 2015.

11.Anonimous. 2011. Dampak Obesitas. Diunduh dari: http://www.strokebethesda.com. Akses: 30 September 2015. 